\title{
Erratum: Very Low Temperature Properties of Liquid Helium-3
}

\section{Louis Goldstein}

Unicersity of Californa, Los Alamos Sctentific Laboratory, Los Alamos, New Mexico 87545

(Received October 23, 1975)

In this paper by Louis Goldstein [J. Low. Temp. Phys. 21, 321 (1975)], the ordinate units in the captions of Figs. $4 \mathrm{a}$ and $4 \mathrm{~b}$ should read $\mathrm{cm}^{3} / \mathrm{mol} \times \mathrm{K}$, instead of $\mathrm{cm}^{3} /$ mole $\times \mathrm{mK}$.

On the right-hand side of Eq. (18), $\left\{1-\left[T / T_{c}(p)\right]^{n}\right\}$ should replace $\left[1-T / T_{c}(p)\right]^{n}$.

On the right-hand side of Eq. (53). a factor of $(1 / T)$ was inadvertently omitted. 